\title{
QUANTITATIVE ANALYSIS OF GALECTIN-3 EXPRESSION IN BENIGN AND MALIGNANT THYROID NODULES
}

\author{
Ivan Šamija ${ }^{1,2}$, Neven Mateša ${ }^{1}$, Sanja Tadinac ${ }^{1}$ and Tomislav Jukić ${ }^{1}$ \\ ${ }^{1}$ Department of Oncology and Nuclear Medicine, Sestre milosrdnice University Hospital Center, Zagreb, Croatia; \\ ${ }^{2}$ Chair of Immunology, School of Dental Medicine, University of Zagreb, Zagreb, Croatia
}

\begin{abstract}
SUMMARY - In this study, galectin-3 was analyzed as a potential marker for preoperative detection of malignant thyroid lesions. Galectin-3 expression was analyzed by quantitative real-time reverse transcription polymerase chain reaction (RT-PCR) in preoperative thyroid fine-needle aspirates from 245 patients with thyroid nodules. Out of 245 samples, 238 were adequate for analysis by RT-PCR. Galectin-3 was positive in 34 (89.5\%) of 38 papillary carcinomas, 3 (89.5\%) of 4 follicular carcinomas, 17 (53.1\%) of 32 follicular adenomas, 2 (33.3\%) of 6 Hurthle cell adenoma, 11 (28.2\%) of 39 Hashimoto thyroiditis, and $69(57.9 \%)$ of 119 nodular goiter samples. Galectin-3 showed specificity of $49.5 \%$, sensitivity of $88.1 \%$, positive predictive value of $27.2 \%$, and negative predictive value of $95.1 \%$ as a marker for detection of malignant thyroid nodules. Owing to the relatively low positive predictive value due to the relatively high false positive rate, the clinical value of galectin-3 analyzed by quantitative real-time RT-PCR as a marker for preoperative detection of malignant thyroid lesions is limited.
\end{abstract}

Key words: thyroid nodule, reverse transcriptase polymerase chain reaction, galectin-3, thyroid neoplasms, fine-needle biopsy

\section{Introduction}

The standard method of preoperatively evaluating thyroid nodules regarding their potential malignancy is fine-needle aspiration (FNA) followed by cytological analysis (1,2). A major limitation of FNA cytology is its inability to differentiate benign (hyperplasia and adenoma) from malignant (follicular carcinoma, follicular variant of papillary carcinoma) follicular thyroid lesions (3). Most of the patients with such cytologically indeterminate diagnosis are treated surgically by thyroidectomy to establish definitive pathological diagnosis. Thyroidectomy has a low but relevant morbidity (injury of recurrent nerves and parathyroid glands) and requires life-long thyroid hormone replacement therapy. Since most of these patients are

Correspondence to: Ivan Šamija, PhD, Department of Oncology and Nuclear Medicine, Sestre milosrdnice University Hospital Center, Vinogradska cesta 29, 10000 Zagreb, Croatia

E-mail: ivan.samija@kbcsm.hr eventually classified as having benign lesions by pathology, thyroidectomy can be considered an unavoidable over-treatment in these patients (4-6).

Many different markers have been studied with the aim of improving the accuracy of preoperative diagnosis of thyroid nodules and consequently avoiding unnecessary thyroidectomies. These include extensive next-generation sequencing panels like the ThyroSeq test that analyses multiple genetic alterations in 112 genes and multiple-gene expression tests like Affirma Gene Expression Classifier that measures the expression of 167 genes (7-9). These panels are relatively expensive, and analysis of single gene expression has some advantages. Galectin-3 has shown the best results so far as a single marker analyzed by immunohistochemistry and immunocytochemistry $(10,11)$. Analysis of galectin-3 expression by reverse transcription polymerase chain reaction (RT-PCR) was performed in fewer studies with inconclusive results. In the largest prospective study of galectin-3 by RT-PCR, it 
showed high sensitivity and negative predictive value, but low specificity and positive predictive value as a marker for preoperative diagnosis of malignant thyroid lesions (12).

In this study, galectin-3 expression was analyzed by quantitative real-time PCR. We propose that quantitative PCR analysis might improve diagnostic accuracy of galectin-3 compared with standard end-point PCR used in previous studies.

\section{Methods}

\section{Samples}

This study included 245 patients with thyroid nodules treated and followed at the Department of Oncology and Nuclear Medicine, Sestre milosrdnice University Hospital Center. All the patients were evaluated by ultrasound-guided FNA as standard diagnostic procedure. Thyroid nodule FNA samples were collected from patients by the cytopathologist using a $25-\mathrm{G}$ needle. After the aspirate was smeared for conventional cytology, the leftover material in the needle was used for galectin-3 expression analysis. Only samples from patients with definitive postoperative histopathologic diagnosis at the time of the conclusion of the study, from patients with definitive cytological diagnosis of nodular goiter, and from patients with definitive preoperative diagnosis of Hashimoto thyroiditis (based on cytology and high titer of antinuclear antibodies) were included in the study. The study was and performed in accordance with the Declaration of Helsinki ethical guidelines and approved by the Ethical Committee of the Sestre milosrdnice University Hospital Center (13).

\section{$R N A$ isolation, reverse transcription and real-time PCR}

TriPure Isolation Reagent (Roche, Indianapolis, IN) was used for RNA isolation from FNA samples, according to the manufacturer's instructions. Reverse transcription was performed using a High Capacity cDNA Reverse Transcription Kit with RNase Inhibitor (Applied Biosystems, Foster City, CA). The reaction mixture consisting of $10 \mu \mathrm{L}$ of isolated RNA and $10 \mu \mathrm{L}$ of $2 \mathrm{X}$ RT master mix was incubated in a thermal cycler for 10 minutes at $25^{\circ} \mathrm{C}, 120$ minutes at 37 ${ }^{\circ} \mathrm{C}$, and a final 5 minutes at $85^{\circ} \mathrm{C}$. Obtained cDNA was stored at $-20{ }^{\circ} \mathrm{C}$ until it was used for real-time PCR.

For real-time PCR reaction, the TaqMan Universal PCR Master Mix (Applied Biosystems) and TaqMan Gene Expression Assay, Assay ID: Hs00173587_m1 (Applied Biosystems) for galectin-3 or TaqMan Endogenous Control, Human GAPD (GAPDH), FAM/ MGB (Applied Biosystems) for glyceraldehyde3-phosphate dehydrogenase (GAPDH) were used. The PCR reaction was performed in a final volume of $25 \mu \mathrm{L}$ with $4 \mu \mathrm{L}$ cDNA in 7500 the Real-Time PCR System (Applied Biosystems). The setup for PCR reaction was: 2 minutes at $52{ }^{\circ} \mathrm{C}, 10$ minutes at $95^{\circ} \mathrm{C}$, and 45 cycles each consisting of 15 seconds at $95^{\circ} \mathrm{C}$ and 1 minute at $60{ }^{\circ} \mathrm{C}$. All samples were analyzed in duplicate. Nontemplate control was included in each experiment.

The $\Delta \Delta \mathrm{CT}$ method was used for the quantification of galectin-3 expression (14), with GAPDH analyzed as the endogenous control. A cDNA from healthy thyroid tissue was used as a calibrator sample for $\Delta \Delta \mathrm{CT}$ quantification. To obtain that cDNA, thyroid tissues immediately after thyroidectomy were inspected by the pathologist who designated a healthy tissue portion from which the FNA sample was obtained. RNA was isolated from FNA samples of healthy thyroid tissue from 7 patients. These RNA isolates were pooled together and converted to cDNA by reverse transcription, as described.

\section{Statistical analysis}

As galectin-3 relative expression values were not normally distributed tested using the KolmogorovSmirnov test, whereas non-parametrical statistical tests were used for comparison between groups regarding galectin-3 expression: Mann-Whitney U test for two groups and Kruskal-Wallis test for more than two groups. When the Kruskal-Wallis test $(p<0.05)$ was positive, post-hoc analysis with a test for pairwise comparison of subgroups was performed. Receiver operating characteristic (ROC) curve analysis was performed to determine the cutoff value for galectin-3 relative expression in discriminating between benign and malignant samples,. All samples with values above the cutoff value were regarded as positive. MedCalc version 10.4.0.0 (MedCalc Software bvba, Mariaker$\mathrm{ke}$, Belgium) was used, and a $\mathrm{p}$ value of $\leq 0.05$ was considered statistically significant. 
Table 1. Distribution of 238 patients with samples adequate for RT-PCR regarding postoperative histopathological and preoperative cytological diagnosis

\begin{tabular}{|l|l|l|l|l|l|l|l|}
\hline \multirow{2}{*}{$\begin{array}{l}\text { Histopathological } \\
\text { diagnosis }\end{array}$} & \multicolumn{7}{|c|}{ Cytological diagnosis /number/ } \\
\cline { 2 - 8 } & $\begin{array}{l}\text { Nondiagnostic } \\
\text { or unsatisfactory }\end{array}$ & Benign & AUS & $\begin{array}{l}\text { Follicular } \\
\text { neoplasm }\end{array}$ & $\begin{array}{l}\text { Suspicious } \\
\text { for malignancy }\end{array}$ & Malignant & Total \\
\hline Papillary carcinoma & 0 & 0 & 2 & 0 & 10 & 26 & 38 \\
Follicular carcinoma & 0 & 0 & 0 & 3 & 1 & 0 & 4 \\
Follicular adenoma & 0 & 3 & 7 & 22 & 0 & 0 & 32 \\
Hurthle cell adenoma & 0 & 2 & 2 & 2 & 0 & 0 & 6 \\
Nodular goiter & 4 & 6 & 8 & 23 & 2 & 0 & 43 \\
Not available & 0 & 115 & 0 & 0 & 0 & 0 & 115 \\
\hline All & 4 & 126 & 19 & 50 & 13 & 26 & 238 \\
\hline
\end{tabular}

* RT-PCR, reverse transcriptase polymerase chain reaction; AUS, atypia of undetermined significance; ${ }^{\text {a }}$ patients did not undergo surgery because definitive preoperative diagnosis of nodular goiter (in 79 patients) or Hashimoto thyroiditis (in 36 patients) was established

\section{Results}

\section{Patients and samples}

The study included 245 patients with thyroid nodules, 47 (19\%) men and 198 (81\%) women. The age of patients ranged from 13 to 81 years, with a median age 48 years. A preoperative FNA sample was taken from each of these patients and analyzed by real-time RTPCR for the expression of galectin-3.

Among 245 samples, 7 (3\%) were inadequate for analysis due to no expression of the GAPDH control gene. Among 238 adequate samples, cytological diagnosis according to Bethesda classification was as follows: nondiagnostic or unsatisfactory in 4 (1.6\%) samples, benign in 126 (52.9\%) samples, atypia of undetermined significance in 19 (8.0\%) samples, follicular neoplasm in $50(21.0 \%)$ samples, suspicious for malignancy in 13 (5.5\%) samples, and malignant (papillary carcinoma) in 26 (10.9\%) samples. Among 126 samples with benign cytological diagnosis, 81 were diagnosed by cytology as nodular goiter, 38 as Hashimoto thyroiditis, and 7 as adenomatoid nodule.

Among 238 adequate samples, 115 (48\%) were from patients with benign cytological diagnosis (79 nodular goiters and 36 Hashimoto thyroiditis) who did not have thyroid surgery during the course of the study. The remaining 123 (52\%) samples were from patients that did undergo thyroid surgery. Postoperative histopathological diagnoses for these samples were the following: papillary carcinoma in 38 samples, follicular carcinoma in 4 samples, follicular adenoma in 32 samples, Hurthle cell adenoma in 6 samples, and nodular goiter in 43 samples. The association between preoperative cytological diagnosis and postoperative histopathological diagnosis is shown in Table 1.

\section{Galectin-3 expression}

Galectin-3 gene expression was studied using realtime RT-PCR. A significant difference in galectin-3 expression was found between groups of patients with different final diagnosis (Kruskal-Wallis test, $\mathrm{p}<0.0001)$. Post hoc pairwise comparison statistical analysis showed a significant difference in galectin-3 expression between the group with final diagnosis of papillary carcinoma and all groups with benign final diagnosis. Furthermore, a significant difference was found between groups with final diagnosis of Hashimoto thyroiditis and follicular adenoma and Hashimoto thyroiditis and nodular goiter. No significant difference in galectin-3 expression was found between other pairs of groups of patients regarding their final diagnosis. The final diagnosis of Hashimoto thyroiditis was based on preoperative FNA cytological analysis and high titer of antinuclear antibodies. The final diagnosis of nodular goiter was based either on postoperative histopathological analysis or on preoperative FNA cytological analysis in patients in which surgery was not performed. All other final diagnoses (papillary carcinoma, follicular carcinoma, follicular adenoma, and Hurthle cell adenoma) were based on postoperative histopathological analysis. 


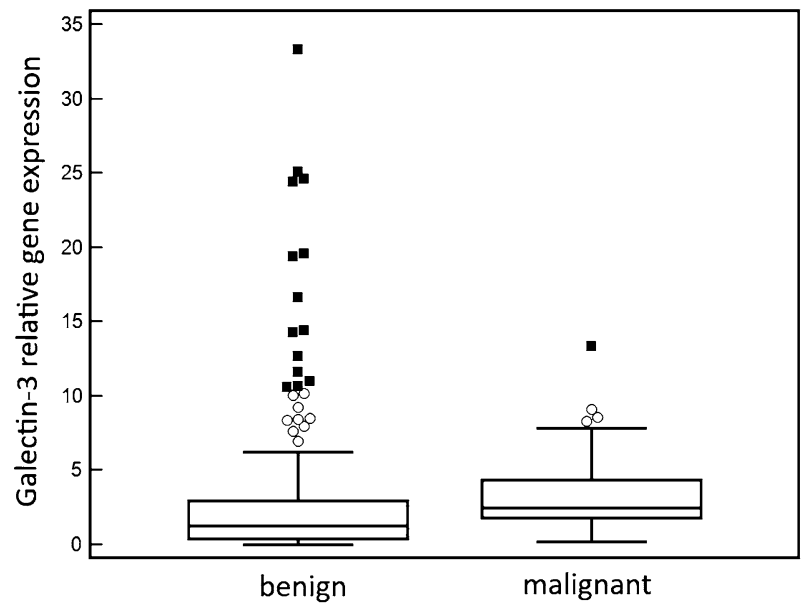

Figure 1. Galectin-3 gene expression in preoperative fine-needle aspiration samples of thyroid nodules with malignant and benign final diagnosis.

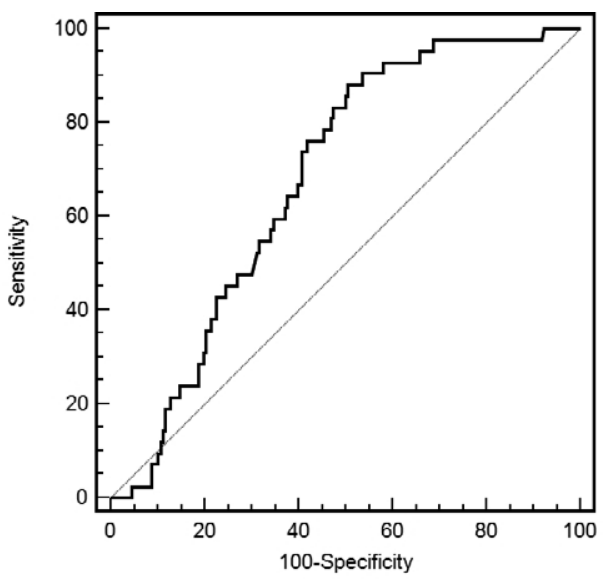

Figure 2. Receiver-operating curve analysis of galectin-3 expression in preoperative fine-needle aspiration samples of thyroid nodules as a marker to discriminate malignant from benign thyroid nodules.

Median galectin-3 gene expression was 2.5 (interquartile range (IQR): 1.8-4.4) in patients with malignant final diagnosis and 1.3 (IQR: 0.4-2.9) in patients with benign final diagnosis. The difference in galectin-3 gene expression between these groups was statistically significant (Mann-Whitney U test, $\mathrm{z}=3.6736$, $\mathrm{p}=0.0002$ ) (Figure 1). There was also a difference in galectin-3 gene expression between patients with malignant final diagnosis and patients with follicular adenoma final diagnosis (median $=1.4, \mathrm{IQR}=0.6$ to 2.3 ) that was statistically significant (Mann-Whitney U test, $\mathrm{z}=3.4299$, $\mathrm{p}=0.0006$ ).
Table 2. Galectin-3 gene expression detected by real-time $R T-P C R$ in preoperative fine-needle aspiration samples of thyroid lesions and preoperative cytological diagnosis

\begin{tabular}{|l|l|l|}
\hline \multirow{2}{*}{ Cytological diagnosis } & \multicolumn{2}{|c|}{ Samples } \\
\cline { 2 - 3 } & $\begin{array}{l}\text { Galectin-3 positive } \\
\text { /number (\%)/ }\end{array}$ & $\begin{array}{l}\text { Total } \\
\text { /number/ }\end{array}$ \\
\hline $\begin{array}{l}\text { Nondiagnostic } \\
\text { or unsatisfactory }\end{array}$ & $3(0.8 \%)$ & 4 \\
$\begin{array}{l}\text { Benign } \\
\text { AUS }\end{array}$ & $63(50.0 \%)$ & 126 \\
Follicular neoplasm & $13(68.4 \%)$ & 19 \\
$\begin{array}{l}\text { Suspicious } \\
\text { for malignancy }\end{array}$ & $25(50.0 \%)$ & 50 \\
Malignant & $9(69.2 \%)$ & 13 \\
\hline All & $23(88.4 \%)$ & 26 \\
\hline
\end{tabular}

*AUS, atypia of undetermined significance

Table 3. Galectin-3 gene expression detected by real-time RT-PCR in preoperative fine-needle aspiration samples of thyroid lesions and final diagnosis

\begin{tabular}{|l|l|l|}
\hline \multirow{2}{*}{ Final diagnosis } & \multicolumn{2}{|c|}{ Samples } \\
\cline { 2 - 3 } & $\begin{array}{l}\text { Galectin-3 positive } \\
\text { /number (\%)/ }\end{array}$ & $\begin{array}{l}\text { Total } \\
\text { /number/ }\end{array}$ \\
\hline Papillary carcinoma $^{\mathrm{a}}$ & $34(89.5 \%)$ & 38 \\
Follicular carcinoma $^{\mathrm{a}}$ & $3(75.0 \%)$ & 4 \\
Follicular adenoma $^{\mathrm{a}}$ & $17(53.1 \%)$ & 32 \\
Hurthle cell adenoma $^{\mathrm{a}}$ & $2(33.3 \%)$ & 6 \\
Hashimoto thyroiditis $^{\mathrm{b}}$ & $11(28.2 \%)$ & 39 \\
Nodular goiter $^{\mathrm{c}}$ & $69(57.9 \%)$ & 119 \\
\hline All & $136(57.1 \%)$ & 238 \\
\hline
\end{tabular}

a diagnosis was established postoperatively by histopathological analysis; ${ }^{b}$ diagnosis was established preoperatively based on FNA cytology and high titer of anti-nuclear antibodies; ${ }^{\mathrm{C}}$ diagnosis was established either preoperatively by FNA cytology or postoperatively by histopathological analysis

Difference in galectin-3 expression was analyzed in a subgroup of patients with unsatisfactory cytological diagnosis or indeterminate cytological diagnosis regarding malignancy according to Bethesda classification. In this subgroup of patients, there was also a difference in galectin- 3 gene expression between patients with malignant (median $=2.5, \mathrm{IQR}=1.8$ to 4.9 ) and benign final diagnosis (median $=1.3, \mathrm{IQR}=0.6$ to 2.7$)$ that was statistically significant (Mann-Whitney U test, $\mathrm{z}=2.508, \mathrm{p}=0.01$ ). 


\section{Galectin-3 diagnostic value}

ROC curve analysis was performed to assess the value of galectin-3 gene expression in discriminating between benign and malignant thyroid nodules (Figure 2). The area under the ROC curve was 0.681 (95\% confidence interval (CI) 0.617-0.739). Using ROC curve analysis, the optimal cutoff value for galectin-3 relative gene expression was set at 1.16 . With this cutoff value, galectin-3 showed a specificity of $49.5 \%$ (95\% CI $42.3-56.7 \%)$, sensitivity of $88.1 \%$ (95\% CI 74.4-96.0\%), positive predictive value of $27.2 \%$ (95\% CI 19.9-35.5\%), and negative predictive value of 95.1\% (95\% CI 88.9-98.4\%).

All samples with galectin-3 expression above the cutoff value were considered positive. The number of positive samples for each cytological diagnosis and for each final diagnosis are presented in Table 2 and Table 3.

\section{Discussion}

Galectin-3 is a lectin, a member of the beta-galactoside binding protein family that plays a role in different cellular functions that are related to malignant transformation such as cellular adhesion, migration, growth, differentiation, and apoptosis (15). Tt has therefore been studied as a potential marker for cancer diagnosis, particularly for thyroid cancer (16). The clinically most relevant application of this marker would be as an ancillary method to FNA cytology to establish accurate preoperative diagnosis of thyroid nodules with indeterminate cytological diagnosis regarding malignancy. Many studies have shown selective expression of galectin-3 in malignant thyroid lesions compared with healthy thyroid tissue and benign lesions (17-20). In the largest multicenter study on 1006 thyroid lesions, immunohistochemical analysis of galectin-3 showed specificity, sensitivity, positive predictive value, and diagnostic accuracy in detecting malignant lesions of $88 \%, 98 \%, 91 \%$, and $97 \%$, respectively (21). In the largest prospective multicenter study in which galectin-3 was evaluated preoperatively on FNA samples from patients with indeterminate cytological diagnosis, it showed a specificity of $93 \%$ and sensitivity of $78 \%$ in discriminating benign from malignant lesions (22).
Unlike most of studies in which galectin-3 expression was evaluated on the protein level using immunochemistry, in our study galectin-3 expression was analysed on the mRNA level using quantitative real-time RT-PCR. The major advantage of RT-PCR compared with immunochemistry is that interpretation of the results does not depend on the subjective evaluation by a trained cytologist.

We have found significantly higher expression of galectin-3 in samples from malignant lesions compared with benign lesions. However, the diagnostic accuracy of galectin-3 in our study was limited, with a specificity of $50 \%$, sensitivity of $88 \%$, positive predictive value of $27 \%$, and negative predictive value of $95 \%$. The limited diagnostic accuracy shown in this study, mostly due to a high false positive rate, is in accordance with previous RT-PCR studies of galectin-3 expression in preoperative thyroid FNA samples (12,23-26). The high false positive rate of galectin-3 expression detected by PCR might be due to galectin-3 expression in other cells present in thyroid FNA samples in addition to thyroid epithelium cells. It has been shown that galectin-3 expression in Hashimoto thyroiditis samples might be due to presence of Hurthle cells that are known to express galectin-3 $(27,28)$. This indicates that immunochemical analysis has an advantage compared with RT-PCR analysis of galectin-3 expression because immunochemistry enables morphological distinction of types of cells expressing galectin-3 in FNA samples.

The hypothesis of the present study was that quantitative real-time PCR used in this study has better diagnostic accuracy compared with end-point PCR used in previous studies of galectin-3 in preoperative FNA samples from thyroid nodules. It was previously shown that real-time PCR has higher sensitivity, dynamic range, and precision than end-point PCR (29). We did not confirm this hypothesis, finding similar limited diagnostic accuracy as shown previously by end-point PCR (12). The reason is that the high false positive rate is due to biology of thyroid, namely expression of galectin-3 in other cells as discussed previously, and not due to the limitations of the method.

The number of samples from patients with follicular thyroid carcinoma was small in our study, which represents a limitation. Incidence of follicular carcinoma is low in Croatia, probably due to complete iodine intake sufficiency, and this study was performed 
on an unselected group of patients with thyroid nodules, so we could not increase the proportion of $\mathrm{pa}^{-}$ tients with follicular thyroid carcinoma (30).

In conclusion, our study has shown that quantitative real-time RT-PCR analysis of galectin-3 expression has limited clinical value in preoperative diagnosis of malignant thyroid nodules, mostly due to low positive predictive value.

\section{References}

1. Gharib H, Goellner JR. Fine-needle aspiration biopsy of thethyroid: an appraisal. Ann Intern Med. 1993;118:282-289.

2. Baloch ZW, LiVolsi VA. Fine-needle aspiration of thyroid nodules:past, present, and future. Endocr Pract. 2004;10: 234-241.

3. Carpi A, Nicolini A, Gross MD, et al. Controversies in diagnosticapproaches to the indeterminate follicular thyroid nodule.Biomed Pharmacother. 2005;59:517-520.

4. Kim ES, Nam-Goong IS, Gong G, et al. Postoperative findings and risk for malignancy in thyroid nodules with cytological diagnosis of the so-called "follicular neoplasms". Korean J Intern Med. 2003;18:94-97.

5. Sorrenti S, Trimboli P, Catania A et al. Comparison of malignancy rate in thyroid nodules with cytology of indeterminate follicular or indeterminate Hurthle cell neoplasm. Thyroid. 2009;19, 355-360.

6. Asari R, Niederle BE, Scheuba $\mathrm{C}$ et al. Indeterminate thyroid nodules: A challenge for the surgical strategy. Surgery. 2010; 148, 516-525.

7. Rossi ED, Pantanowitz L, Faquin WC. The Role of Molecular Testing for the Indeterminate Thyroid FNA. Genes (Basel). 2019;10(10):736.

8. Nikiforova MN, Mercurio S, Wald AI, et al. Analytical performance of the ThyroSeq v3 genomic classifier for cancer diagnosis in thyroid nodules. Cancer. 2018;124(8):1682-1690.

9. Jug RC, Datto MB, Jiang XS. Molecular testing for indeterminate thyroid nodules: Performance of the Afirma gene expression classifier and ThyroSeq panel. Cancer Cytopathol. 2018; 126(7):471-480.

10. Griffith OL, Chiu CG, Gown AM, Jones SJ, Wiseman SM. Biomarker panel diagnosis of thyroid cancer: a critical review. Expert Rev Anticancer Ther. 2008;8(9):1399-1413.

11. Chiu CG, Strugnell SS, Griffith OL, et al. Diagnostic utility of galectin-3 in thyroid cancer. Am J Pathol. 2010;176(5): 2067-2081.

12. Šamija I, Mateša N, Lukač J, Kusić Z. Galectin-3 and CD44v6 as markers for preoperative diagnosis of thyroid cancer by RT-PCR. Diagn Mol Pathol. 2011;20(4):233-241.

13. World Medical Association. World Medical Association Declaration of Helsinki: ethical principles for medical research involving human subjects. JAMA. 2013;310(20):2191-2194.
14. Livak KJ, Schmittgen TD. Analysis of relative gene expression data using real-time quantitative PCR and the 2(-Delta Delta C(T)) Method. Methods. 2001;25(4):402-408.

15. Wang L, Guo X-L. Molecular regulation of galectin-3 expression andtherapeutic implication in cancer progression. Biomed Pharmacother. 2016;78:165-171.

16. Trimboli P, Virili C, Romanelli F, Crescenzi A, Giovanella L. Galectin-3 Performance in Histologic a Cytologic Assessment of Thyroid Nodules: A Systematic Review and Meta-Analysis. Int J Mol Sci. 2017;18(8):1756.

17. Sanabria A, Carvalho AL, Piana de Andrade V, et al. Is galectin-3 a good method for the detection of malignancy in patients with thyroid nodules and a cytologic diagnosis of "follicular neoplasm"? A critical appraisal of the evidence. Head Neck. 2007;29(11):1046-1054.

18. Gasbarri A, Martegani MP, Del Prete F, Lucante T, Natali PG, Bartolazzi A. Galectin-3 and CD44v6 isoforms in the preoperative evaluation of thyroid nodules. J Clin Oncol. 1999;17 (11):3494-3502.

19. Papotti M, Rodriguez J, De Pompa R, Bartolazzi A, Rosai J. Galectin-3 and HBME-1 expression in well-differentiated thyroid tumors with follicular architecture of uncertain malignant potential. Mod Pathol. 2005;18(4):541-546.

20. Carpi A, Rossi G, Coscio GD, et al. Galectin-3 detection on large-needle aspiration biopsy improves preoperative selection of thyroid nodules: a prospective cohort study. Ann Med. 2010;42(1):70-78.

21. Bartolazzi A, Gasbarri A, Papotti M, et al. Application of an immunodiagnostic method for improving preoperative diagnosisofnodularthyroidlesions.Lancet.2001;357(9269):1644-1650.

22. Bartolazzi A, Orlandi F, Saggiorato E, et al. Galectin-3-expression analysis in the surgical selection of follicular thyroid nodules with indeterminate fine-needle aspiration cytology: a prospective multicentre study. Lancet Oncol. 2008;9(6):543-549.

23. Pineda P, Rojas P, Liberman C, et al. Detection of malignancymarkers in thyroid nodules by reverse transcriptase polymerasechain reaction (RT-PCR). Rev Med Chil. 2003;131: 965-972.

24. Pagedar NA, Chen DH, Wasman JK, et al. Molecular classificationof thyroid nodules by cytology. Laryngoscope. 2008;118: 692-696.

25. Aratake Y, Umeki K, Kiyoyama K, et al. Diagnostic utility ofgalectin-3 and CD26/DPPIV as preoperative diagnostic markers forthyroid nodules. Diagn Cytopathol. 2002;26:366-372.

26. Martins L, Matsuo SE, Ebina KN, et al. Galectin-3 messengerribonucleic acid and protein are expressed in benign thyroid tumors. J Clin Endocrinol Metab. 2002;87:4806-4810.

27. Niedziela M, Maceluch J, Korman E. Galectin-3 is not an universalmarker of malignancy in thyroid nodular disease in children andadolescents. J Clin Endocrinol Metab. 2002;87: 4411-4415.

28. Matesa N, Samija I, Kusic Z. Galectin-3 and CD44v6 positivity byRT-PCR method in fine needle aspirates of benign thyroid lesions. Cytopathology. 2007;18:112-116. 
29. Gál AB, Carnwath JW, Dinnyes A, Herrmann D, Niemann H, Wrenzycki C. Comparison of real-time polymerase chain reaction and end-point polymerase chain reaction for the analysis of gene expression in preimplantation embryos. Reprod Fertil Dev. 2006;18(3):365-371.
30. Kusić Z, Novosel SA, Dabelić N, et al. Croatia has reached iodinesufficiency. J Endocrinol Invest. 2003;26:738-742.

Sažetak

Kvantitativna analiza ekspresije galektina-3 u benignim i malignim čvorovima štitnjače

\section{I. Šamija, N. Mateša, S. Tadinac i T. Jukić}

U ovom istraživanju galektin-3 je istraživan kao potencijalni biljeg za predoperativnu detekciju malignih lezija štitnjače. Ekspresija galektina-3 je analizirana kvantitativnom lančanom reakcijom polimerazom nakon reverzne transkripcije (RT-PCR) u stvarnom vremenu u predoperativnim aspiratima tankom iglom 245 bolesnika s čvorovima štitnjače. Uzorci 238 bolesnika od ukupno 245 su se pokazali adekvatnima za RT-PCR analizu. Galektin-3 je bio pozitivan u 34 (89.5\%) od 38 uzoraka papilarnog karcinoma, 3 (89.5\%) od 4 uzorka folikularnog karcinoma, 17 (53.1\%) od 32 uzorka folikularnog adenoma, 2 (33.3\%) od 6 uzoraka adenoma Hurthleovih stanica, 11 (28.2\%) od 39 uzoraka Hashimotovog tiroiditisa i 69 (57.9\%) od 119 uzoraka nodularne strume. Kao biljeg za razlikovanje malignih od benignih čvorova štitnjače, galektin-3 je pokazao specifičnost od $49.5 \%$, osjetljivost od $88.1 \%$, pozitivnu prediktivnu vrijednost od $27.2 \%$ i negativnu prediktivnu vrijednost od $95.1 \%$. Zbog relativno niske pozitivne prediktivne vrijednosti uslijed relativno velikog broja lažno pozitivnih rezultata, klinička vrijednost određivanja galektina-3 kvantitativnim RT-PCR-om u stvarnom vremenu kao biljega za predoperativnu detekciju malignih čvorova štitnjače je ograničena.

Ključne riječi: čvor u štitnjači, lančana reakcija polimerazom nakon reverzne transkripcije, rak štitnjače, biopsija tankom iglom 